\title{
PEMBENAHAN WEB PROFIL SINODE GEREJA KRISTEN JAWA
}

\author{
Budi Susanto $^{1^{*}}$, Laurentius Kuncoro Probo Saputra ${ }^{2}$ \\ 1,2 Fakultas Teknologi Informasi Universitas Kristen Duta Wacana \\ Jl. Dr. Wahidin Sudirohusodo No.5-25, Kotabaru, Gondokusuman, Yogyakarta 55224 \\ * Penulis korespondensi; Email: budsus@ti.ukdw.ac.id
}

\begin{abstract}
Abstrak: Web Sinode GKJ telah mengalami beberapa kali perubahan. Penyediaan aplikasi web yang selama ini dilakukan secara mandiri pada akhirnya memunculkan masalah. Masalah utama yang dihadapi adalah berkaitan dengan keberlanjutan pengembangan dan keamanan. Untuk menjawab kebutuhan tersebut, maka Sinode GKJ bersama FTI UKDW telah melaksanakan pembenahan ulang untuk web Sinode GKJ dengan memanfaatkan Wordpress. Dalam pembehanan tersebut, dilakukan analisis terhadap kebutuhan informasi dan publikasi konten yang dibutuhkan jemaat anggota Sinode GKJ, dan perancangan arsitektur informasi. Berdasar rancangan arsitektur informasi, tim pengabdi menyiapkan website lalu mendampingi tim Pusat Data Informasi dan Layanan Media Sinode GKJ untuk penerapan dan pengisian konten. Wordpress telah dipasang pada layanan VPS dengan tambahan protokol keamanan SSL yang memberikan kepastian lebih untuk mendukung pengembangan dan keamanan selanjutnya. Kegiatan ini akan dilanjutkan pada tahap selanjutnya yang secara khusus berkaitan dengan penyediaan layanan manajemen dokumen.
\end{abstract}

Kata kunci: Sinode GKJ; web; gereja; wordpress.

\begin{abstract}
The GKJ Synod Web has been amended several times modifications independently. It led to a vulnerability condition that cost system breaches. Building the web application independently in limited security resource was the main problem for GKJ Synod. In order to resolve the problem, the GKJ Synod collaborated with FTI UKDW. Wordpress was implemented to restore the the GKJ Synod web. The restoration process, requirement and content analysis, and information architecture design. Based on the information architecture design, the website had been setup and then the team empowered the Data and Multimedia Information Service Center of GKJ Synod to maintain the web application and the contents. The installed WordPress utilised the VPS service with an additional SSL security protocol that provides development support and security. Thie web application project will continue to the next stage which is online document management services.
\end{abstract}

Keywords: GKJ synode; web; church; wordpress.

\section{PENDAHULUAN}

Sinode GKJ telah mulai mengembangkan aplikasi web dan dipublikasikan sejak tahun 2001 sebagai upaya untuk menjawab kebutuhan penyebaran informasi yang lebih baik dan memudahkan kepada jemaat dan umatnya. Informasi yang terpublikasikan pada web tersebut sudah sangat banyak, antara lain terkait dengan Bahan Pembinaan, Profil Sinode GKJ dan Gereja-gerejanya, Lembaga-lembaga sinode. Dengan kondisi infrastruktur Internet di Indonesia saat itu, dapat dikatakan sebagai sebuah keberadaan awal Internet di Indonesia, Sinode GKJ telah mengambil langkah yang sangat luar biasa. Penyediaan layanan Web Sinode GKJ dapat dikatakan sebagai sebuah tahap penting bagaimana gereja memanfaatkan teknologi informasi dan komunikasi untuk mendukung pelayanannya.
Dalam perkembangannya, web Sinode telah mengalami beberapa penyesuaian. Gambar 1 menunjukkan contoh gambaran terkait web profil Sinode GKJ pada tahun Mei 2001.

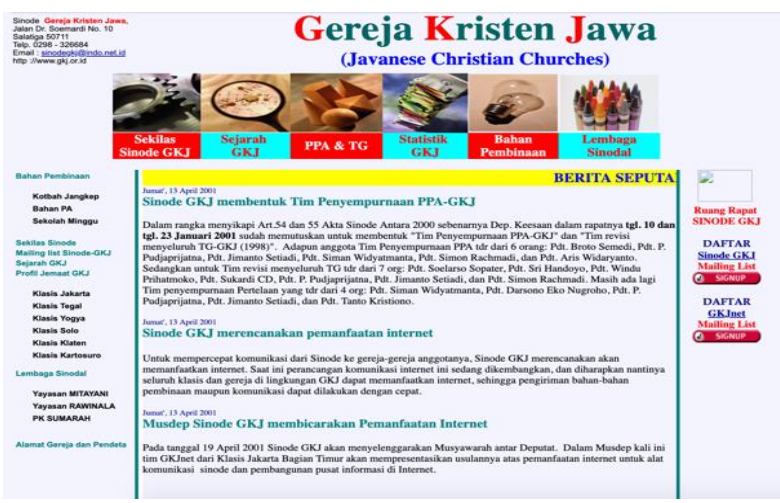

Gambar 1. Halaman Web Sinode GKJ tahun 2001 (Sumber: http://web.archive.org/web/20010521135158/http:// gkj. or.id/) 
Kemudian pada awal tahun 2002, web tersebut telah mengalami perubahan, seperti ditunjukkan pada Gambar 2. Pada web tersebut tidak banyak terjadi perubahan terhadap arsitektur informasinya, hanya saja yang berubah adalah tata letak dan warna. Namun yang paling mencolong adalah undangan untuk bergabung ke mailing list yang dikelola Sinode GKJ makin terlihat. Pada akhirakhir tahun 2002, sekitar mulai bulan September 2002, beberapa kali terdeteksi web sinode GKJ tidak dapat diakses.

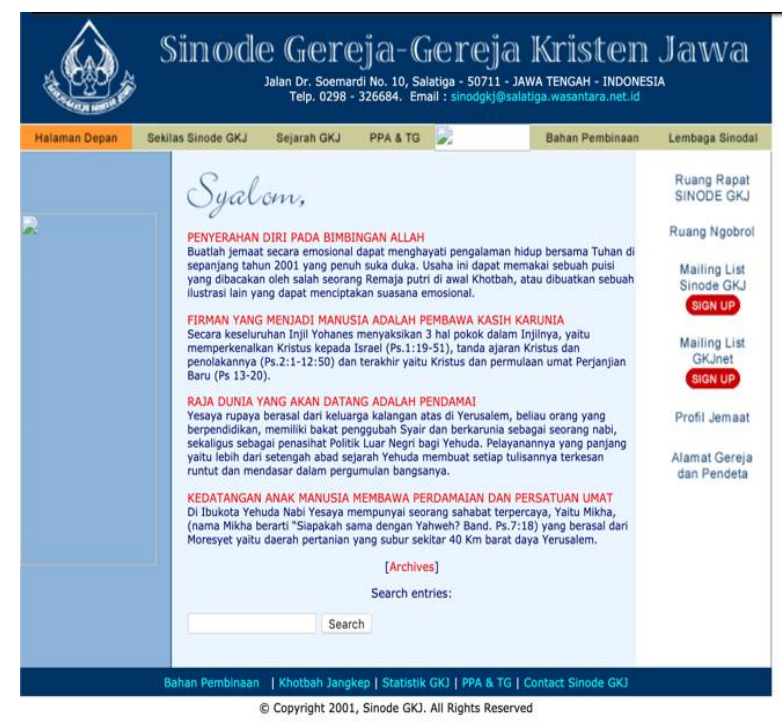

Gambar 2. Halaman Web Sinode GKJ tahun 2002 (Sumber: http://web.archive.org/web/20020122064134/http:// gkj.or.id/)

Website tersebut masih terus digunakan sampai dengan sekitar tahun 2005, dilakukan restrukturisasi dan pengembangan ulang. Pengembangan ulang ini membutuhkan waktu yang relatif sedikit lama, sampai pada sekitar bulan Oktober 2007 dipublikasikan Web Sinode GKJ sebagai web revisi ke-3, seperti ditunjukkan pada Gambar 3.

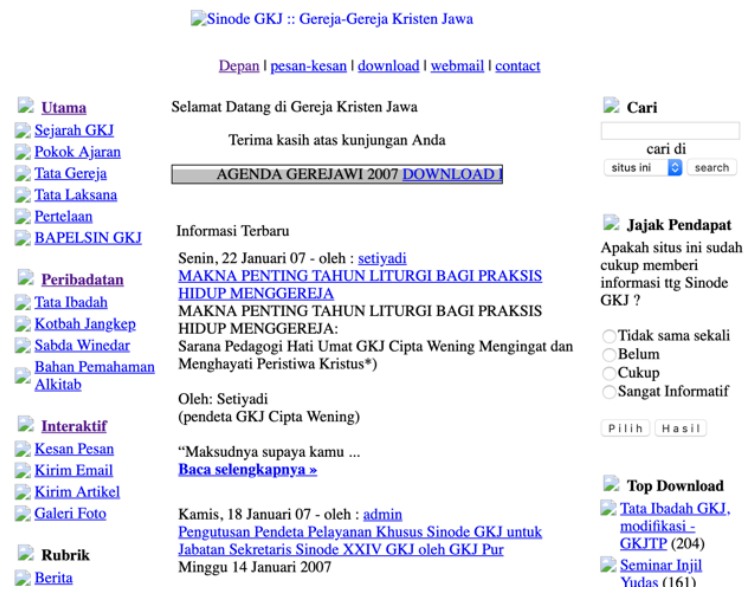

Gambar 3. Gambaran Web Sinode GKJ Tahun 2007 (Sumber: http://web.archive.org/web/20070204011724/http:// www.gkj.or.id/main/)
Web profil Sinode GKJ mulai tahun 2007 telah banyak mengalami perubahan terkait informasi yang dipublikasikan. Penambahan informasi terkait profil Sinode GKJ lengkap termasuk Pokok Ajaran, Tata Gereja, Tata Laksana sudah mulai dipublikasikan. Bahan-bahan pengajaran juga bertambah.

Oleh karena kebutuhan informasi yang perlu dipublikasikan semakin beragam, maka pada sekitar bulan Juli 2011, dipublikasikan web yang lebih "segar" dan beragam informasinya yang ditampilkan, seperti ditunjukkan pada Gambar 4.

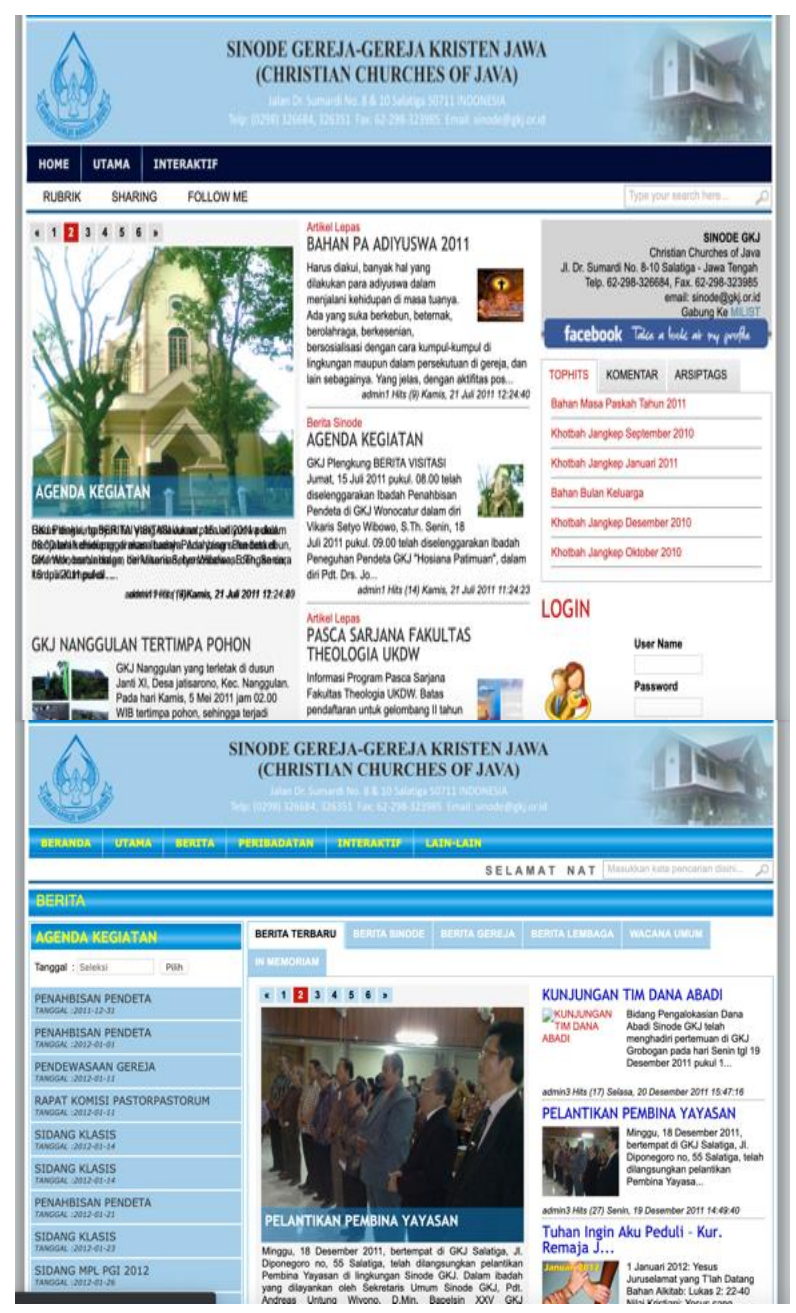

Gambar 4. Gambaran Web Sinode GKJ pada Juli 2011 dan akhir Juli 2011 (Sumber: http://web.archive.org/web/ 20110721121212/http://gkj.or.id/)

Pada sekitar pertengahan Agustus 2017, mulai muncul permasalahan terkait dengan keamanan web. Website Sinode GKJ sempat di suspend oleh penyedia (lihat Gambar 5) setidaknya sebanyak 9 kali sejak 24 Agustus 2017 sampai dengan 27 Januari 2019 (Internet Archive, 2019). Beberapa kali juga web Sinode GKJ berhasil di crack oleh orang tidak dikenal, setidaknya yang sempat dilaporkan oleh PDILM (Pusat Data Informasi dan Layanan Media) Sinode GKJ adalah dari bulan Oktober 2018 - Februari 2019. 

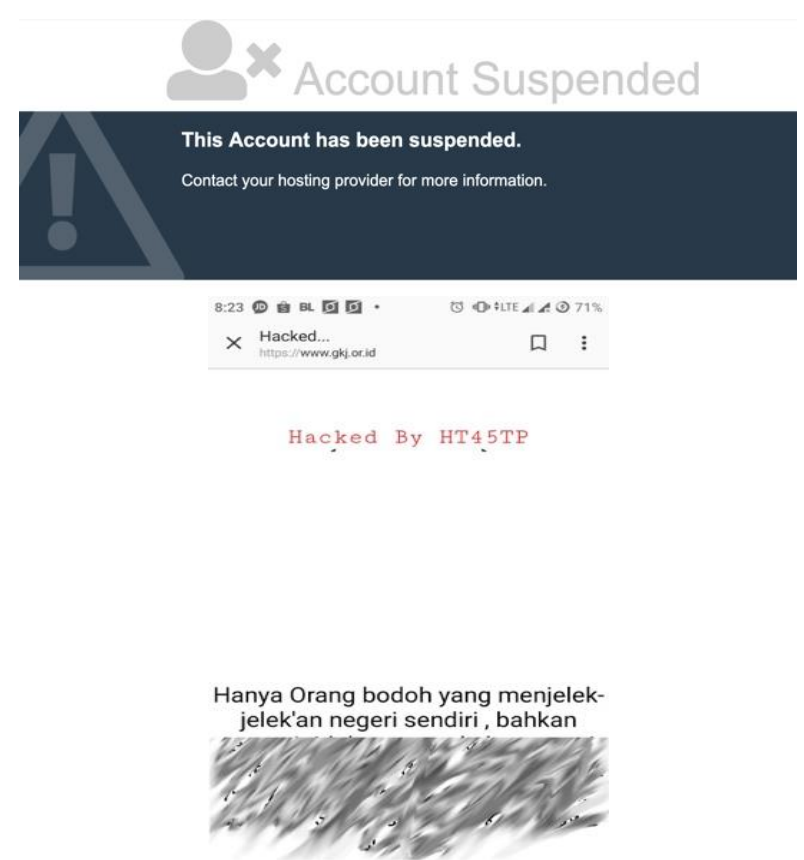

Gambar 5. Web Sinode GKJ sempat di suspend karena banyaknya serangan

Kekayaan informasi yang disajikan pada web profil sangatlah beragam. Dari sejarah pengembangan yang telah diuraikan secara umum sebelumnya, terlihat bahwa ada permasalahan terkait dengan bagaimana menyediakan suatu platform aplikasi content management system yang mampu menjawab dinamisnya konten serta tanggap terhadap perubahan teknologi web yang ada saat ini. Pengembangan platform yang sering berganti menyebabkan ketidakkonsistenan dalam penanganan terhadap konten dan terlebih lagi juga menghabiskan banyak biaya dan sumber daya waktu dan manusia.

Berdasar dua kondisi masalah utama tersebut, yaitu masalah keamanan dan ketersediaan kerangka aplikasi CMS yang memadai, maka Sinode GKJ selanjutnya bekerjasama dengan FTI UKDW untuk mulai melakukan pembenahan. Dalam beberapa kali diskusi awal, telah disepakati metode pembenahan dan sekaligus penentuan kerangka aplikasi CMS yang akan digunakan, yaitu Wordpress.

\section{METODE PELAKSANAAN}

Pembangunan Web yang mempublikasikan profil gereja telah banyak dilakukan. Beberapa pengembangan yang terekam dalam publikasi, antara lain untuk GKI Sinode Wilayah Jawa Tengah (Susanto, 2016), Gereja GKPMI Pamen Medan (Jiimmy, 2018), GMIM Getsemani Paal IV Manado (Panggalo, 2014), Gereja Damai Kristus (Agens, 2013), Gereja Huria Kristen Indonesia Purwakarta (Hutaganol \& Zakaria, 2019), Gereja Misi Injili Indonesia Jemaat Sola Gratia (Putra,
Darmianto, \& Luinome, 2016), Gereja House of Filadelfia di Jakarta Selatan (Nauli \& Musa, 2017).

Pada umumnya aplikasi-aplikasi web tersebut dikembangkan dari awal dengan menggunakan bahasa pemrograman PHP. Tahapan pengembangan juga dilakukan dengan prinsip life cycle development, yaitu mulai dari pendefinisian kebutuhan, perancangan, pengembangan, dan penerapan. Hal yang banyak tidak dibahas dan mungkin dilakukan adalah pengujian dan penerapan secara langsung.

Pada kegiatan pengabdian yang telah dilakukan untuk website Sinode GKJ ini dilakukan dengan metodologi yang mungkin sedikit berbeda pada umumnya. Metodologi pengembangan dapat ditunjukkan pada Gambar 6. Metodologi tersebut dilakukan mengingat bahwa kondisi Website Sinode GKJ yang ada saat mulai disesuaikan adalah masih aktif. Sehingga yang menjadi pertimbangan utama adalah data-data lama yang sudah ada sebelumnya.

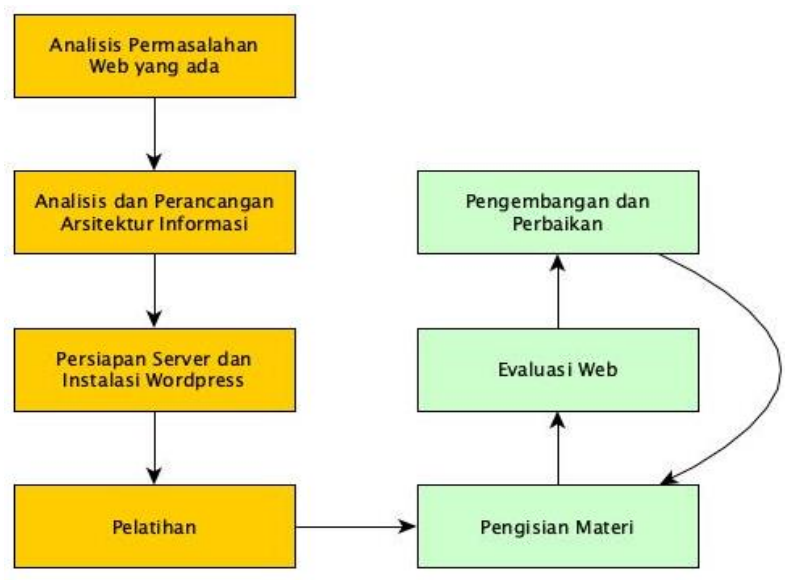

Gambar 6. Metodologi Pengembangan Web Sinode GKJ

Tahapan pertama yang dilakukan adalah menganalisis kondisi website dan hosting yang digunakan oleh Sinode GKJ yang beralamatkan di gkj.or.id. Berdasarkan hasil analisis tersebut, dilakukan tahap perancangan arsitektur informasi yang diharapkan dapat menyederhanakan informasi yang ditampilkan, namun tetap dapat memenuhi kebutuhan jemaat dan masyarakat.

Berdasarkan arsitektur informasi yang dirancang, langsung dilanjutkan dengan penerapannya. Dengan mempertimbangkan bahwa perlu adanya faktor kemudahan dalam pemeliharaan web dan konten yang ada, maka dalam pengembangan ini diputuskan bersama untuk menggunakan Aplikasi CMS Wordpress. Tahap selanjutnya adalah persiapan server dan instalasi Wordpress termasuk protokol SSLnya. Setelah dilakukan pengujian, aplikasi web Sinode GKJ dapat mulai digunakan. Dalam hal pengisian konten web, dilakukan pelatihan terlebih dahulu kepada bagian PDILM Sinode GKJ yang terdiri dari seorang kepala dan 2 
staf. Melalui staf PDILM dilakukan pengisian data secara berkala. Berdasarkan penerapan tahap awal tersebut, dilakukan evaluasi. Evaluasi meliputi kendala dan rencana pengembangan berikutnya. Hal ini perlu dilakukan untuk menjamin keberlangsungan dan kemandirian Sinode GKJ dalam pengelolaan Webnya.

\section{HASIL DAN PEMBAHASAN}

Kegiatan awal yang dilakukan adalah melakukan analisis terhadap permasalahan yang dihadapi oleh Sinode GKJ terkait dengan pengembangan web profilnya. Pada tanggal 22 Februari 2019 dilakukan diskusi awal antara tim pengabdi dengan tim dari Sinode GKJ bertempat di Fakultas Teknologi Informasi UKDW Yogyakarta (Lihat Gambar 7). Dalam pembahasan tersebut akhirnya diputuskan bahwa untuk penyediaan layanan web profil Sinode GKJ akan menggunakan platform CMS Wordpress. Pemilihan Wordpress sebagai platform didasarkan berbagai pertimbangan keuntungan dan kerugian. Salah satu dasar pertimbangan adalah berdasar pendapat Erick Decker (2019) yang menegaskan bahwa Wordpress berlisensi GNU Public License (GPL), mudah dipasang dan digunakan, mudah dalam pemeliharaan, dan banyak plugin dan theme.

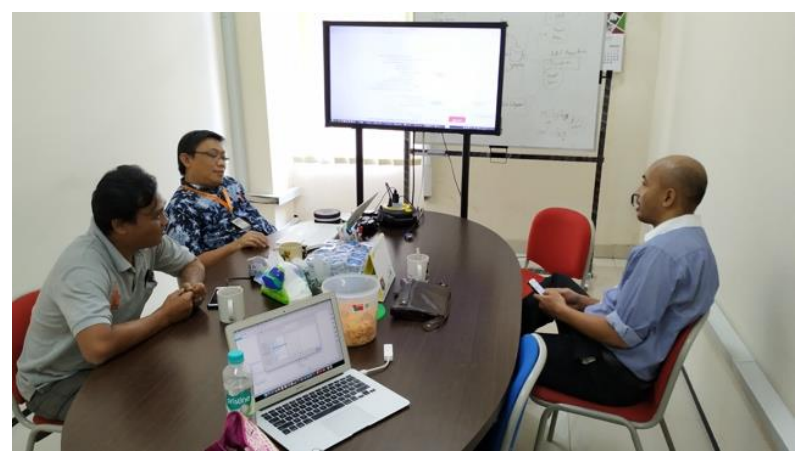

Gambar 7. Pertemuan Perdana untuk Analisis Kebutuhan Web

Sedangkan untuk mendukung keamanan web hosting, disepakati untuk menggunakan layanan Virtual Private Network (VPS) dengan kapasitas Virtual Processor 4 Core, Ram 4 Gbyte, dan penyimpanan 60 Gbyte. Pemilihan ini didasarkan pada rencana ke depan, yaitu selain web, akan disediakan juga aplikasi untuk mendukung manajemen dokumen yang memudahakan bagi Sinode untuk berbagi dan berkolaborasi.

Berdasar pertemuan awal tersebut, tim pengembang bersama PDILM mulai mengurus penyewaan VPS. Tim pengembang membantu untuk setup domain, instalasi Wordpress, dan juga web service nginx dengan SSL. Oleh karena Sinode GKJ memiliki 2 domain, yaitu gkj.or.id dan sinodegkj. or.id, maka perlu dipertimbangkan beberapa hal. Web lama yang bermasalahan diletakkan pada domain gkj.or.id, sedangkan sinodegkj.or.id selama ini digunakan sebagai cadangan. Kondisi lain adalah karena domain gkj.or.id sudah ditempelkan pada aplikasi Google App Suite, maka akan sedikit kesulitan dalam pengelolaan karena proses setup ulang. Sehingga berdasarkan hal tersebut diputuskan bahwa untuk web Sinode GKJ yang baru akan ditempatkan pada VPS dengan domain sinodegkj. or.id, sedangkan pada hosting gkj.or.id akan digunakan hanya untuk redirect. Langkah ini akan dilakukan pada fase konversi tahap pertama.

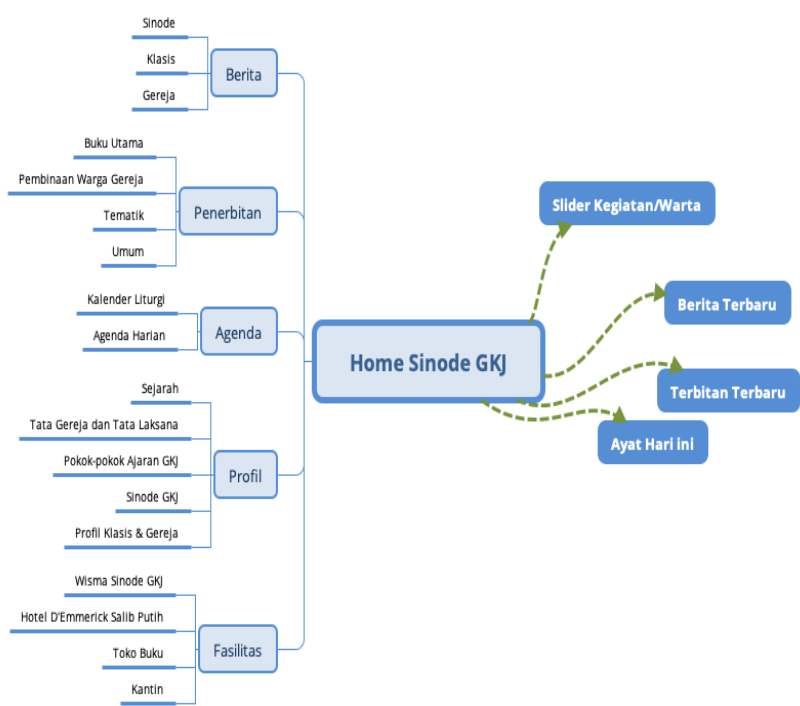

Gambar 8. Rancangan Struktur Informasi Web Sinode GKJ

Bentuk penerapan dari rancangan struktur web Sinode GKJ yang ditunjukkan pada Gambar 8 telah berhasil dilakukan. Untuk menterjemahkan struktur tersebut ke dalam Wordpress, pemanfaatan fasilitas Kategori artikel menjadi penting. Adapun bentuk bentuk penerapan Wordpress untuk web Sinode GKJ yang baru dapat diakses di https://sinodegkj.or.id atau https://gkj.or.id yang otomatis akan diteruskan ke domain sinodegkj.or.id (Lihat Gambar 9).

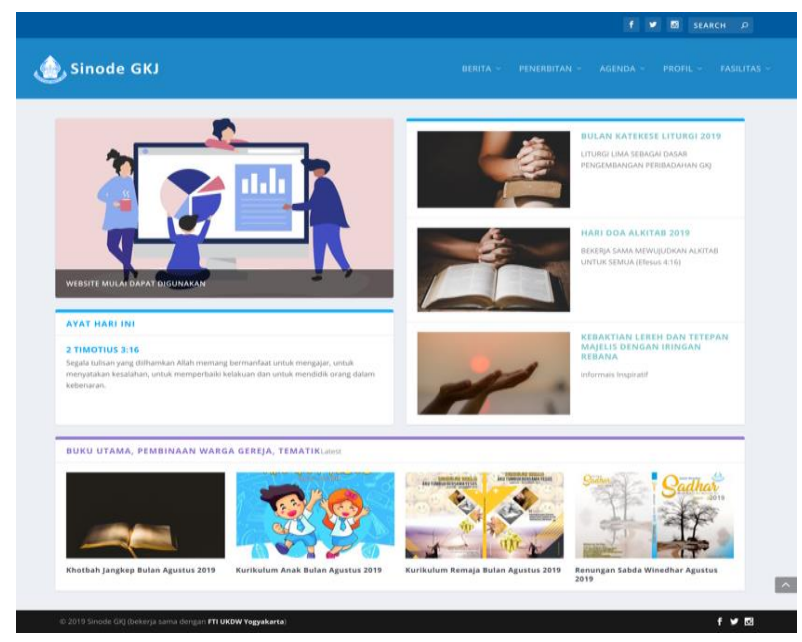

Gambar 9. Contoh Halaman Home Sinode GKJ 
Untuk proses pengisian dan tindak lanjut penggunaan Web Sinode GKJ yang baru, maka telah dilakukan pelatihan kepada tim PDILM Sinode GKJ. Pelatihan telah dilakukan pada tanggal 12 April 2019 bertempat di Kantor Sinode GKJ Salatiga (Lihat Gambar 10).

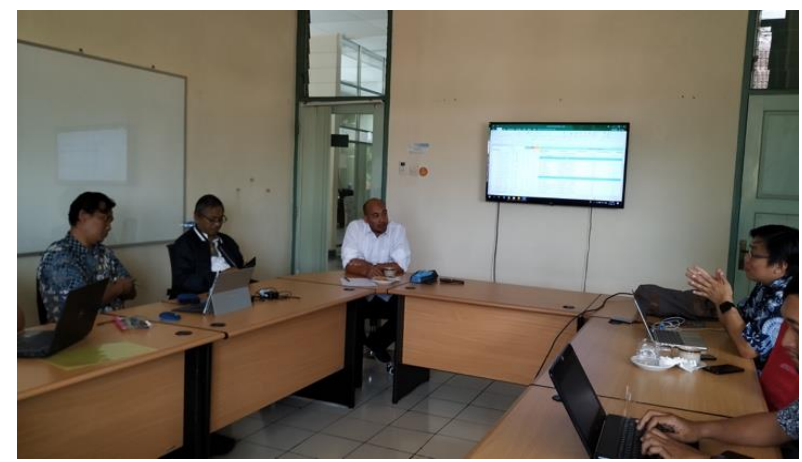

Gambar 10. Pelatihan Penggunaan Web Sinode GKJ

Pelatihan dinilai cukup dilakukan sekali mengingat tenaga SDM di PDLM Sinode GKJ telah memiliki pengalaman yang baik dalam penggunaan Wordpress. Penekanan pelatihan difokuskan pada beberapa hal penting terkait dengan metadata yang harus diperhatikan dalam setiap artikel yang dibuat. Sedangkan perihal teknis lain yang dibutuhkan untuk penggunaan Wordpress telah banyak dikuasai oleh tim PDILM Sinode GKJ.

Dari penerapan tahap pertama tersebut, telah dilakukan juga evaluasi yang pada prinsipnya menilai bahwa web Sinode GKJ berbasis Wordpress saat ini telah dapat digunakan dan disepakati sebagai dasar layanan publikasi berikutnya. Namun demikian oleh karena informasi yang tersedia pada web saat ini masih tergolong sederhana, maka diusulkan beberapa pengembangan web selanjutnya. Adapun beberapa ide pengembangan yang harus dikerjakan selanjutnya, antara lain: a) perlunya Wordpress plugin yang menyediakan fungsi untuk penyediaan informasi terkait dengan profil klasis dan setiap gereja; b) perlunya Wordpress plugin yang dapat digunakan untuk agenda bacaan Alkitab dan ayat nats harian; serta c) perlu untuk segera disediakan layanan manajemen dokumen sebagai wadah layanan distribusi dokumen.

Evaluasi lain adalah yang masih belum dapat dilakukan sampai saat ini adalah mengkonversi dari data-data lama ke web yang baru. Permasalahan atau kendala utama yang dihadapi adalah tidak kompatibilitasnya platform web lama, yang dikembangkan secara mandiri berbasis PHP, dengan platform Wordpress.

Terhadap hasil-hasil evaluasi telah disepakati juga bahwa tahap kegiatan Pengabdian kepada Masyarakat selanjutnya terkait dengan pengem- bangan web Sinode GKJ adalah untuk konversi data lama ke web baru, penyediaan plugin yang telah disepakati berdasar hasil evaluasi, dan juga sosialisasi kepada gereja-gereja berkaitan dengan operasional web yang baru.

\section{SIMPULAN}

Kegiatan pendampingan pembuatan web Sinode GKJ, yang merupakan juga bentuk konversi dari web lama, telah berjalan dengan baik. Pengelolaan web Sinode GKJ baru yang sudah berjalan saat ini telah ditangani oleh tim PDILM Sinode GKJ dan akan terus melakukan pengisian konten secara bertahap. Tim FTI UKDW akan membantu secara berkelanjutan berkaitan dengan hal-hal teknis, secara khusus dalam pengembangan. Namun demikian, beberapa kendala yang masih dialami menjadi catatan penting untuk kegiatan pengabdian kepada masyarakat di Sinode GKJ selanjutnya.

\section{UCAPAN TERIMA KASIH}

Dalam kegiatan pengabdian kepada masyarakat ini, tim pengabdi mengucapkan terima kasih kepada Sinode GKJ, secara khusus Departemen Penelitian dan Pengembangan serta PDILM (Pusat Data Informasi dan Layanan Media) yang telah banyak terlibat dan memberikan dukungan penuh untuk kegiatan ini. Tidak lupa tim pengabdi menyampaikan terima kasih kepada LPPM UKDW yang telah mendukung dalam pendanaan tahun 2019.

\section{DAFTAR PUSTAKA}

Agens. (2013). Pembuatan Program Aplikasi Website Gereja Damai Kristus. Jurnal Ilmu Komputer dan Sistem Informasi (JIKSI), 1(2), 14-18.

Decker, E. (2019, Juli 1). Why WordPress? 7 Benefits of WordPress Websites. Retrieved 7 20, 2019, from GoDaddy: https://www.godaddy. com/garage/why-wordpress-benefits-wordpress-websites/

Hutaganol, M. P., \& Zakaria, T. M. (2019). Rancang Bangun Website Gereja Huria Kristen Indonesia Purwakarta didukung Google-Calendar. Sarana Tugas Akhir Mahasiswa Teknologi Informasi (STRATEGI), 1(1), 58-67.

Internet Archive. (2019, Juli 26). Retrieved from Wayback Machine: http://web.archive.org/ web/*/http://gkj.or.id/cgi-sys/suspendedpage.cgi

Jiimmy. (2018). Perancangan Web Profil Bagi Umat Beragama Kristen (Studi Kasus Gereja GKPI Pamen Medan). Jurnal Ilmiah Core It, 105112. 
Nauli, S., \& Musa. (2017). Perancangan Situs Web untuk Informasi Pelayanan Jemaat Gereja House of Filadelfia di Jakarta Selatan. Jurnal Satya Informatika, 1-13.

Panggalo, R. A. (2014). Perancangan Sistem Informasi Gereja Berbasis Web (Studi Kasus Jemaat Gmim Getsemani Paal Iv Manado). Politeknik Negeri Manado, Jurusan Teknik Elektro. Manado: Politeknik Negeri Manado.
Putra, A. Y., Darmianto, A., \& Luinome, C. Y. (2016). Perancangan Website Gereja Misi Injili Indonesia (GMII) Jemaat Sola Gratia. Jurnal InTekSis, 3(2), 11-18.

Susanto, B. (2016). Pemanfaatan Teknologi Web Sebagai Media Komunikasi Gki Sinode Wilayah Jawa Tengah. Seminar Nasional Hasil Pengabdian kepada Masyarakat (SENDIMAS 2016). Yogyakarta: UKDW. 